\title{
From collecting to cultivation: transitions to a production economy in the Near East
}

\author{
George Willcox $\cdot$ Mark Nesbitt $\cdot$ Felix Bittmann
}

Received: 12 January 2012/ Accepted: 17 January 2012/Published online: 4 February 2012

(C) Springer-Verlag 2012

The selected articles in the current issue throw new light on our understanding of how Homo sapiens became caught in the agriculture trap in the Near East. They are the outcome of the session entitled 'Origins of agriculture in the Near East' held at the 15th IWGP conference in Wilhelmshaven 2010. The subject is constantly being revised as new information and more refined analyses become available, so these papers provide a state of the art in 2010/2011. Each major discovery adds complexity to what has become a multi-faceted puzzle with data being drawn from disciplines as wide apart as archaeology and genetics, plant biology and palaeo-climatology. In this issue papers concentrate on results obtained from charred plant remains and their interpretation. During the last half of the 20th century ground-breaking scholars like Hans Helbaek, Daniel Zohary, Maria Hopf, Willem van Zeist and Gordon Hillman made major contributions (Zohary and Hopf 1973; Helbaek 1959; Hillman 1984; Van Zeist and Bakker-Heeres 1982). Daniel Zohary combined genetics and information from living progenitors with Maria Hopf's archaeobotanical knowledge to help explain the domestication of plants in the Near East. Willem van Zeist pioneered the

\section{G. Willcox $(\square)$}

Archéorient, UMR 5133, CNRS Jalès, 07460 St-Paul-le-Jeune, France

e-mail: gwillcox@wanadoo.fr

\section{Nesbitt}

Herbarium, Royal Botanic Gardens, Kew, Richmond,

Surrey TW9 3AB, UK

e-mail: m.nesbitt@kew.org

\section{F. Bittmann}

Lower Saxony Institute for Historical Coastal Research,

Viktoriastr. 26/28, 26382 Wilhelmshaven, Germany

e-mail: bittmann@nihk.de identification and sampling of charred seeds from early Neolithic sites while Gordon Hillman developed interpretive tools for the subject. Their findings opened up avenues for hypothesizing as to how, when and why, in south west Asia, humans started systematically cultivating a selection of grain crops. In the 1980s and 1990s the puzzle appeared quite simple because it was composed of few elements and so scholars hypothesized using straightforward deterministic scenarios and models citing climate change, or population growth, or over-exploitation as possible factors which encouraged humans to adopt cultivation. Today the central elements of these hypotheses are still valid, but with hindsight simple hypotheses are no longer plausible given the archaeological and environmental diversity within the Fertile Crescent. This complex diversity is exemplified by the vast geographical area where transition sites are located, which spans different climate and vegetation zones. Thus, sites in the north of the Fertile Crescent are 1,000 km from those in the south and likewise in the east-west direction. Archaeological diversity is exemplified by the extended chronological range of transition sites. We can trace the use of wild cereals back to about 23,000 years ago when habitations consisted of simple brush huts to villages with sophisticated architecture associated with the earliest domesticated cereals 12,500 years later.

The transition to a production based economy was acted out on a vast stage of multi-dimensional cultural developments. Archaeological and archaeobotanical discoveries represent only narrow windows providing unconnected fleeting glimpses of human subsistence economies. Gaps in the archaeological record may result from lack of survey work but also because early Neolithic sites are often buried beneath large Bronze Age mounds, for example at Tell el Kerkh, Motza, Tell Qaramel and Cheik Hassan. Others may be covered by post occupation alluvial sediments. 
Despite these limitations our understanding of this vital period of human history is improving as the seven papers presented in this volume demonstrate.

Over the past 20 years a great deal of new archaeobotanical and archaeological information has been collected concerning this key development for the history of humanity. Here, we highlight just a few of these discoveries in relation to papers presented. For example the exceptional discoveries and detailed analyses of charred remains by Mordechai Kislev from sites such as Ohalo II and Netiv Hagdud (Kislev 1997) in the southern Levant, or finds which show that some crops were abandoned (Melamed et al. 2008). In this volume Chantel White and Cheryl Makarewicz add new information from southern Jordan with their results from the site of el-Hemmeh, while Eleni Asouti and Dorian Fuller have provided a much needed regional review for the area. Whereas the southern Levant is the location of key sites excavated in the 1960s and 1970s, such as Jericho and Tell Aswad, most of the major new datasets of the last two decades, with the notable exceptions of Ohalo II and Netiv Hagdud, have come from the northern Fertile Crescent. In large part this is because of dam-building and associated salvage archaeology along the Euphrates, leading to more sites being excavated in the north. Large-scale flotation of comparable, relatively large sites, would be highly desirable in the southern Levant, particularly in the light of increasing evidence for diverse pathways to agriculture within different zones of the Fertile Crescent (Fuller et al. 2011, see also Kuijt and Finlayson 2009). In the northern Fertile Crescent the unearthing of the monumental sculptured monoliths at Göbekli Tepe and complex food processing rooms provided a glimpse into the cultural sophistication associated with early cereal use (Neef 2003; Willcox 2002). New information from this area is provided by Simone Riehl et al. with results from their analyses at Kortik Tepe. In northern Syria sites dated to the beginning of the Holocene such as Tell Qaramel, and Euphrates sites such as Jerf el Ahmar, Dja'de and Tell 'Abr show a surprisingly dense concentration with the possibility of pre-domestic cultivation (Willcox et al. 2008). The recognition of sites where morphologically wild cereals were cultivated was first proposed by Willem van Zeist and Gordon Hillman. Sue Colledge pioneered work on arable weeds as indicators of cultivation of wild pulses and cereals (Hillman et al. 2001; Colledge et al. 2004; Colledge and Conolly 2010). Now there are at least 10 sites where archaeobotanical evidence suggests pre-domestic cultivation. In this volume George Willcox develops this theme by comparing a restricted number of weed taxa from a wide chronological range of sites. The question of "When and where did domesticated cereals first occur in southwest Asia?", the title of Mark Nesbitt's much-cited 2002 paper is still a hot subject. Then, Tanno and Willcox attempt to provide better criteria for identifying morphological domestication which they apply to a number of sites. Their first paper on the subject published in 2006 provided new data for the debate on "How fast was wild wheat domesticated?". The archaeobotanical data, including Van Zeist's early work, demonstrates that mixtures of wild and domestic crops were used together, suggesting slow rates of domestication. Genetics and in particular DNA analyses of living populations pioneered by Francesco Salamini and Terry Brown and colleagues has added pieces to the puzzle of domestication. Early results on einkorn were interpreted in terms of a simple rapid monophyletic domestication but more recent DNA studies which include other species are adding complexity to the puzzle. Future studies will hopefully clarify whether crops have monophyletic as opposed to polyphyletic origins. In the present volume Dorian Fuller et al. provide evidence for a protracted model for the origins of agriculture (Fuller 2007; Allaby et al. 2010; Purugganan and Fuller 2011; see also discussion in Honne and Heun 2009 and Haldorsen et al. 2011). Most of the raw data in this contribution, which was presented at Wilhelmshaven, has been published before (Purugganan and Fuller 2011), but because there are some new aspects, e.g., a substantial discussion of the evidence from the Near East and more details on the duration of pre-domestication cultivation, localisation of hotspots and of delaying factors, and because of the different readership of the two journals we accepted this contribution as a 'Discussion'.

The geographical extent of early agriculture sites is widening, for example with the discovery of early farming communities on the island of Cyprus which are contemporary or earlier than the earliest signs of cereal domestication on the continent. Leilani Lucas et al. throw new light on the subject with their contribution to this volume. Other new evidence of sites in Iran is provided by Simone Riehl et al. in this volume, and it is likely that further excavations in the Zagros will show that the eastern Fertile Crescent is not the peripheral zone sometimes assumed. New PPNA sites have been found on Cyprus and in upland areas in central Syria on the Jebel Balaas located away from permanent water. The archaeobotanical studies from these sites have not yet been published.

Future research will refine and modify our understanding of the origins of agriculture in the Near East. Work on the modern distribution and ecology of wild progenitors is still insufficient (Abbo et al. 2010; Willcox 2005) as is work on the ethnobotany and processing of gathered plants (exceptions being Fairbairn et al. 2006; Mason and Nesbitt 2009; Wollstonecroft et al. 2011). On the horizon are discoveries such as exceptionally well preserved Natufian plant remains from Dederiyeh cave in north west Syria which date to the Younger Dryas (Tanno et al. in press), or finds of emmer from the new excavation of the PPNA site 
of Klimonas on the island of Cyprus, and early PPNB levels now under excavation at Aşıklı in central Anatolia. These new discoveries will no doubt enable us to progress in our understanding of how, why and when human societies adopted cultivation in the Near East as their major food procurement activity.

\section{References}

Abbo S, Lev-Yadun S, Gopher A (2010) Yield stability: an agronomic perspective on the origin of Near Eastern agriculture of consumers of centrally organised food distribution. Veget Hist Archaeobot 19:143-150

Allaby RG, Brown TA, Fuller DQ (2010) A simulation of the effect of inbreeding on crop domestication genetics with comments on the integration of archaeobotany and genetics: a reply to Honne and Heun. Veget Hist Archaeobot 19:151-158

Colledge S, Conolly J (2010) Reassessing the evidence for the cultivation of wild crops during the Younger Dryas at Tell Abu Hureyra, Syria. Env Archaeol 15:13-124

Colledge S, Conolly J, Shennan S (2004) Archaeobotanical evidence for the spread of farming in the Eastern Mediterranean. Curr Anthropol 45(suppl):S35-S58

Fairbairn A, Martinoli D, Butler A, Hillman GC (2006) Wild plant seed storage at Neolithic Çatalhöyük East, Turkey. Veget Hist Archaeobot 16:467-479

Fuller D (2007) Contrasting patterns in crop domestication and domestication rates: recent archaeobotanical insights from the old world. Ann Bot 100:903-909

Fuller D, Willcox G, Allaby R (2011) Cultivation and domestication had multiple origins: arguments against the core area hypothesis for the origins of agriculture in the Near East. World Archaeol 43:628-652

Haldorsen S, Akan H, Çelik B, Heun M (2011) The climate of the Younger Dryas as a boundary for Einkorn domestication. Veget Hist Archaeobot 20:305-318

Helbaek H (1959) Domestication of food plants in the old world. Science 130:365-372

Hillman GC (1984) Interpretation of archaeological plant remains: the application of ethnographic models from Turkey. In: Van Zeist W, Casparie WA (eds) Plants and ancient man. Studies in Palaeoethnobotany. Balkema, Rotterdam, pp 1-41

Hillman G, Hedges R, Moore A, Colledge S, Pettitt P (2001) New evidence of Late Glacial cereal cultivation at Abu Hureyra on the Euphrates. Holocene 11:383-393
Honne BI, Heun M (2009) On the domestication genetics of selffertilizing plants. Veget Hist Archaeobot 18:269-272

Kislev M (1997) Early agriculture and palaeoecology of Netiv 483 Hagdud. In: Bar-Yosef O, Gopher A (eds) An early Neolithic 484 village in the Jordan valley. Peabody Museum of Archaeology 485 and Ethnology. Harvard University, Cambridge, pp 209-236

Kuijt I, Finlayson B (2009) Evidence for food storage and predomestication granaries 11,000 years ago in the Jordan Valley. PNAS 106:10,966-10,970

Mason S, Nesbitt M (2009) Acorns as food in southeast Turkey: implications for prehistoric subsistence in Southwest Asia. In: Fairbairn A, Weiss E, (eds) From foragers to farmers: papers in honour of Gordon C. Hillman. Oxbow Books, Oxford, pp 71-85

Melamed Y, Plitzmann U, Kislev M (2008) Vicia peregrina: an edible early Neolithic legume. Veget Hist Archaeobot 17:29-34

Neef R (2003) Overlooking the steppe forest: preliminary report on the botanical remains from early Neolithic Göbekli Tepe (southern Turkey). Neolithics 2/03:13-15

Purugganan MD, Fuller DQ (2011) Archaeological data reveal slow rates of evolution during plant domestication. Evolution 65:171-183

Tanno K, Willcox G, Muhesen S, Nishiaki Y, Kanjo Y, Akazawa T (in press) Preliminary results from analyses of charred plant remains from a burnt Natufian building at Dederiyeh cave in northwest Syria. In: Bar-Yosef O, Valla F (eds) The Natufian Culture of the Levant II. International Monographs in Prehistory, Ann Arbor

Van Zeist W, Bakker-Heeres JH (1982) Archaeobotanical studies in the Levant, 1. Neolithic sites in the Damascus Basin: Aswad, Ghoraife, Ramad. Palaeohistoria 24:165-256

Willcox G (2002) Charred plant remains from a late tenth millennium kitchen at Jerf el Ahmar (Syria). Veget Hist Archaeobot 11: $55-60$

Willcox G (2005) The distribution, natural habitats and availability of wild cereals in relation to their domestication in the Near East: multiple events, multiple centres. Veget Hist Archaeobot 14: $534-541$

Willcox G, Fornite S, Herveux L (2008) Early Holocene cultivation before domestication in northern Syria. Veget Hist Archaeobot $17: 313-325$

Wollstonecroft MM, Hroudováz, Hillman GC, Fuller DQ (2011) Bolboschoenus glaucus (Lam.) S.G. Smith, a new species in the flora of the ancient Near East. Veget Hist Archaeobot 20: $457-468$

Zohary D, Hopf M (1973) Domestication of pulses in the old world. Science 182:887-894 